\title{
Lexicalisation Patterns of Rendering Path Descriptions in Polish Translation from English
}

\author{
Dorota ChlopeK \\ University of Bielsko-Biała; Bielsko-Biała, Ul. Willowa 2, \\ PL-43-309Bielsko-Biała,dorotach@ath.bielsko.pl
}

SCN V/2 [2012], 37-55

Članek govori o izrazito dvokategorijalni tipologiji jezikov, ki jo je razvil Talmy. Raziskovalec izpostavlja jezike, ki pot ali cilj označijo zunaj glagolskega okvira (»satelitsko uokvirjeni jeziki«), ter jezike, ki pot ali cilj označijo znotraj glagola (»glagolsko uokvirjeni jeziki«), in sicer v smislu združevanja semantične komponente poti - bodisi kot »satelitsko« umeščene ob načinovni glagol ali ob glagolski koren. Slobin je to tipologijo razširil z uvedbo razreda ekvivalentno uokvirjenih jezikov. Angleščina in poljščina sta oba satelitsko uokvirjena jezika, vendar avtorica ugotavlja, da angleščina pogovorno izraža ideje s strukturami, ki leksikalizirajo natančno pot skozi satelite, poljski prevod pa to pot nevtralizira, spreminja ali opušča pot, izraženo $\mathrm{v}$ originalu.

The article pertains to the powerful bi-categorial typology of languages developed by Talmy. The researcher generally points at satellite-framed languages and verb-framed languages in terms of conflating the semantic component of path, either to a satellite placed near a manner verb or to a verb root. Slobin expanded that typology by introducing a class of equipollently framed languages. English and Polish are both satellite-framed languages. Nonetheless, while English colloquially expresses ideas with constructions lexicalising precise path through satellites, Polish translation renders the path, neutralises it, changes it, or omits the path conveyed by the original version, which is illustrated by this paper.

Ključne besede: Talmy, tipologija, prevajanje, vzorec, angleščina, poljščina

Key words: Talmy, typology, translation, pattern, English, Polish 


\section{Introduction}

The article focuses on Polish translation of English utterances that express a route of movement or a situation of being located in relation to Talmy's bicategorial typology developed for satellite-framed languages and verb-framed languages (see Talmy 1985, 2000). Talmy's typology is based on colloquial use. The satellite conflating path in satellite-framed languages is in a sister relation to the verb root (Talmy 2000: 222), for example a verb particle in English and a verb prefix in Polish. Verb-framed languages characteristically map the core schema or the path into the verb (see idem). The thesis in this article is that although English and Polish are both categorised as satellite-framed languages (see Slobin 2003: 163), Polish employs a less precise path in communicating the information that will naturally have that path when expressed in English, in utterances with satellites. Nevertheless, Polish has a verbal potential to express numerous situations with the semantic component of path. That potential is given by abundant prefixes, called satellites, and by prepositions, ${ }^{1}$ often correlating with the prefixes. Such constructions, however, may not convey a specific path, the path may be neutral. For example, expressions with the prefix prze- and the correlating preposition przez with a nominal complement in the accusative case can render English utterances with over, as in On przeskoczyt przez plot 'He has jumped over the fence', with through, as in Hałas przeszedt przez ścianę 'The noise came through the wall', and with across, as in On przedostat sie przez rzeke 'He got across the river'. The Polish examples above specify the path 'to the other side' by means of the nominal complements of the preposition przez, which are marked for the accusative case, a spatial case in Polish (see Krążyńska 2000: 41). What is more, while a native speaker of English may instruct the interlocutor to approach him or her saying Come over here, with over in the 'to the other side of' sense, or Come here, or just Come, the same information in Polish, Chodź tutaj or $t u$ 'Come here or here', or just Chodz' 'Come', will omit the distance 'to the other side of' encoded in over in Come over here. The distance is evoked by the verb chodz' 'come', and it is implicitly conveyed by the deictic index form tutaj or $t u$ 'here', marking the endpoint of the path in the Polish version. English communicates it with the verb come and, additionally, explicitly, with the particle over, marking the distance 'to the other side of'. Moreover, in another example, off in Take your

${ }^{1}$ Zaron (2005: 49) indicates that the thesis about a stronger relation of a Polish preposition to the noun following it than to the verb preceding it is deeply controversial. Saloni and Świdziński explain that prepositionality is a selective dictionary category of real 'właściwych', and not real 'niewłaściwych', verb lexemes 'leksemów czasownikowych'. Its values are conventional names of prepositional lexemes. These lexemes most often consist of one element. In order to achieve transparency of the value of the selective category of prepositionality, the researchers do not use the label prepositional lexeme but they use the label of a pair consisting of the word that is an exponent of the prepositional form and the name of the case, e.g., O $+A c c$ 'About + the Accussative case' (c.f. Saloni, Świdziński 2007: 130). 
hands off me expresses a precise path, either real or metaphorical, the Polish version however is Zostaw mnie 'Leave me', without path. It has 13 results in the demonstrative corpus of the $\mathrm{PWN}^{2}$ Corpus of the Polish language at [URL: http://korpus.pwn.pl] and 10 results in the PAN ${ }^{3}$ Corpus of the Polish language at [URL: http://korpus.pl]. The utterance Zostaw mnie 'Leave me', is also used as equivalent to Take your hands off me in the meaning Zostaw mnie w spokoju 'Leave me in peace', with 3 results in the PWN Corpus (op. cit) and 2 results in the PAN Corpus (op. cit). Nevertheless, the reading of Zostaw mnie, 'Leave me', depends on the context, on the particular usage event. Although Polish has a rude utterance with path that corresponds to the path expressed by Take your hands off me, which is Zabierz ode mnie swoje łapy 'Take your grabbers off me', this utterance has no results in the PWN Corpus and in the PAN Corpus, respectively. The colloquial English language is saturated with the semantic component of path. Neutralising or reducing the path of motion, also omitting that semantic component, is observed in Polish utterances (see Chłopek 2008a, b; 2010a, b). Thus, the objectives of this paper are to present certain translational problems related to expressing the "intricate" trajectories of movement encoded through English constructions in Polish. Those problems are illustrated through the patterns for rendering English utterances with the semantic component of motion event and path into Polish.

Motion evoked by verbs has recently drawn a response from several Slavic researchers, for example in the volume New Approaches to Slavic Verbs of Motion, edited by Hasko and Perelmutter (2010, Amsterdam and Philadelphia, John Benjamins). Kopecka examines the relationship between typology and the semantic variety of Manner verbs in Polish (idem, 227). Filipovic focuses on the expression of motion events in Serbo-Croatian in the context of Talmy's (1985) typology (idem, 247). According to the researcher, Not all manner of motion verbs can be freely used in all motion expression, as in the case of English, due to lexical and morphosyntactic restrictions (Filipović 2010: 249). Filipović argues that the restrictions that are presented in her paper affect the lexicalization of motion events in Serbo-Croatian and, as a result, its position within Talmy's typology (idem). Nikitina focuses on the issue of encoding the endpoint of motion in Russian. The researcher claims that the set of expressions a language may use to describe directed motion is typically not limited to one construction. Alternative ways of expressing the same meaning can be used with different or partly overlapping classes of verbs (Nikitina 2010: 287). Rakhilina presents a thorough analysis of five Russian and five Polish verbs, both cognates and not (2010: 291). The researcher explains that there is a considerable difference between verbal frames of rotation lexicalized in both languages despite their close relations (idem). Gor, Cook, Malyushenkova and Vdovina, together, pertain to the bi-categorial typology developed by Talmy

\footnotetext{
2 PWN stands for Państwowe Wydawnictwo Naukowe, an established Polish publisher of academic texts.

${ }^{3}$ PAN stands for Państwowa Akademia Nauk 'National Academy of Sciences'.
} 
$(1985,2000)$. The researchers analyse Russian verbs of motion in the process of second language acquisition (Gor et al, 2010: 361). The articles in Hasko and Perelmutter's volume referred to above suggest that Talmy's influential typology opens areas for further investigation into the place of Slavic in the satellite-framed typology. This paper contributes to this research field the finding that while English colloquially expresses ideas with utterances lexicalising precise paths, Polish translation preserves the path, changes it, neutralises the original precise path, or omits it. This paper focuses on path in both languages, not on manner or generally on motion. Although motion may be present in the translation Polish version, the originally expressed specific and explicit path may not be evoked by it.

This paper shows examples referring to several ways of processing the originally expressed path in the translation Polish version. It consists of three main parts following this introduction. The first part is a general presentation of basic aspects of Talmy's bi-categorial typology based on patterns of lexicalising path. The second part is the main body of the text. It presents ways or patterns observed in expressing the original information conveyed by English pathconstructions in Polish. Those patterns were identified by the author through earlier research, following and analysing translations from colloquial English into Polish, for example oral translations in films (see Chłopek 2008a, b), like Take your hands off me 'Zostaw mnie'. In this paper the patterns are demonstrated on the basis of examples (1a) to (14a) from J. K. Rowling's Harry Potter and the Order of Phoenix (2003: 1-145), rendered by Andrzej Polkowski under the title Harry Potter $i$ Zakon Feniksa (2004, Poznań, Media Rodzina), examples (1b) to (14b). The third part of the paper attempts to formulate possible reasons for different lexicalisations of the same information in both satellite-framed languages respectively: with specific path in English and with either preserved or general, reduced or omitted path in Polish.

\section{A general insight into the typology of satellite and verb-framed languages}

According to Talmy's bi-categorial typology with respect to verbalising the semantic component of path, present in motion event, languages are generally either satellite-framed class or they are within the verb-framed category (1985). While the former group has verb satellites that express the path, morphemes added to verb roots, free or bound, the latter group encodes that component of motion in the root verb. For example, English and Polish, respectively, are both categorised as satellite-framed languages since they express the path with satellites: English with verb particles, which are free morphemes, for example down in the sentence She took down the suitcase, Polish with verb prefixes, which are bound morphemes, for example the prefix $z$-in the sentence Ona zdjęła walizke 'She took down the suitcase'. Talmy has introduced a new grammatical category, which is a satprep, a blend created of a satellite and a 
preposition, based on another blend, an adprep, composed of an adverb and a preposition, introduced by Bolinger (1971: 26-31). Bolinger illustrated an adprep with the following sentence, with the adprep off : She swept off the stage (idem). The researcher explained that adpreps are portmanteau words, fusions of elements that are syntactically distinct but semantically identical (Bolinger 1971: 31). Talmy used satprep in the description of motion event (e.g., 2003: 108). The researcher treats a situation containig motion or the continuation of a stationary location alike as a 'Motion event' /.../ (Talmy 2007 [1985]: 70). Constructionally, adpreps or satpreps seem to belong to the verb as much as to the following noun phrase. A satellite is a verb particle, it is an adverb, an adjunct. A particle is the only complement which can freely come between the verb and its direct object (Huddleston and Pullum 2010 [2005]: 144). For example, it is correct to say She took down the suitcase and She took the suitcase down (c.f. idem). A preposition immediately precedes its nominal complement, for example off in the phrase off the stage in the imperative Off the stage!. In traditional grammar, prepositions are bound in constituency to a following noun phrase, whereas adverbial particles are more bound to the verb. Huddleston and Pullum extend the preposition category (see idem, 128-134). Nevertheless, this paper considers prepositions as additional to satellites in expressing the path and sometimes categorised as adpreps or satpreps, in Talmy's terms, like off in the sentence She swept off the stage (Bolinger, op. cit). According to Talmy, Generally, the Path is expressed fully by the combination of a satellite and a preposition (2007 [1985]: 141).

If a path - quoting Slobin (2003: 116) - has several components, each is typically expressed by a separate verb in a verb-framed language: schematically: 'exit the house - cross the field - enter the forest'. This "heavy" sequence of clauses can be compacted in a clause with a single verb in a satellite-framed language: run-out of the house, across the field, into the forest. To illustrate these contextual situations with two contrastive utterances, Slobin (2003: 163) provides an example from English and from French, respectively. French is a verb-framed language:

(1) The dog went into the house.

(2) Le chien est entré dans la maison.

Slobin argues that Slavic languages are also satellite-framed, but present a problem (2003: 120). Since the path satellites in the Slavic languages are verb prefixes, Slavic use separate verbs for path segments (see idem). For example, Polish takes a number of verb prefixes with manner verbs, like in the following examples with the stem frunać 'fly': przyfrunac (z powrotem) 'fly back', dofrunąc 'fly to', nadfrunać 'fly to', wfrunać 'fly into', przefrunać 'fly through/across/over', podfrunać 'fly near to', sfrunać 'fly off (from)', odfrunać 'fly away (from)', wyfrunać 'fly out (of)'. Prepositions may complete the path designated by the satellite, which is another term for a post-verbal particle (see Talmy 2003 [2000]b: 107). 
Talmy explains that English has a number of verbs that genuinely incorporate path (1985 [2007]: 92), such as: enter, exit, ascend, descend, cross, pass, circle, advance, proceed, approach, arrive, depart, return, join, separate, part, rise, leave, near, follow. Nevertheless, those verbs are not the most characteristic type in English, since the great majority are borrowings from Romance, where they are the native type. What is more, those verbs do not predominate in everyday speech. They tend to occur in formal language, not in colloquial communication.

Talmy has distinguished several other participants than the Path in the Motion event, such as the Figure, the Ground, and the semantic component of Manner. ${ }^{4}$ Languages that express manner through verb roots, such as English, for example through the manner verb fly, communicate path through a movement verb and a satellite, which is the particle accompanying the verb, for example fly back, where the particle back occurs with the main verb fly, as in He flew back to London $^{5}$. Verb-framed languages, for example French, communicate the manner of movement, called the co-event, with an adjunct, either the prepositional phrase or the gerundive (Talmy 2003 [2000]b: 224). It means that there is a subordinate expression of manner together with the verb conveying the path (see Slobin 2004: 25). For example, the freedictionary.com gives the following translation of the example He flew back to London into French, where the prepositional phrase en avion expresses the manner of motion: 'Il est revenu à Londres en avion' (literally: 'He returned to London by plane').

Talmy analyses motion events with real or factive motion (see Talmy 2003 [2000]b) and with fictive motion. Fictive motion is connected with a category of emanation paths (Talmy 2003 [2000]a: 115). Among them, there is a path belonging to visual paths. That emanation path explains the path evoked by looked up at Fudge in (8a) and looking down at the jumble in (14a), among the examples in part two. According to Talmy (2003 [2000]a: 115),

This type of fictive motion involves the conceptualization of two entities, the Experiencer and the Experienced, and of something intangible moving in a straight path between the two entities in one direction or the other. By one branch of this conceptualization, the Experiencer emits a Probe that moves from the Experiencer to the Experienced and detects it upon encounter with it. This is the "Experiencer as Source" type of sensory path. By the other branch of the conceptualization, the Experienced emits a Stimulus that moves from the Experienced to the Experiencer and sensorily stimulates that entity on encountering it. This is the "Experienced as Source" type of sensory path. Sight, in particular, is thus either treated as a probing system that emanates from or is projected forth by a viewer so as to detect some object at a distance, or it is treated as a visual quality that emanates from some distal object and arrives at an individual, thereby stimulating a visual experience.

\footnotetext{
${ }^{4}$ The Motion event and the components of the event are written with capital initial letters by Talmy (see e.g., 1985 or 2000). In this paper, those words start with a lower-case letter.

${ }^{5}$ See [URL: http://thefreedictionary.com].
} 
Therefore, relating to Talmy, this paper has examples with factive and fictive motion, real and not real, expressed in part two. Talmy presented two main categories of languages: satellite-framed and verb-framed languages (see 1985). Slobin contributed a type of equipollently-framed languages to Talmy's influential bi-categorial typology. The researcher proposed a tripartite typology with regard to path expression /.../ (Slobin 2004: 26). Slobin (2004: 25) defines an equipollently-framed language in the following way:

Path and manner are expressed by equivalent grammatical forms. The typical construction types, depending on language, are:

- MANNER VERB + PATH VERB: serial-verb languages (Niger-Congo, Hmong-Mien, Sino-Tibetan, Tai-Kadai, Mon-Khmer, Austronesian)

- [MANNER + PATH]VERB: bipartite verb languages (Algonquian, Athabaskan, Hokan, Klamath-Takelman)

- MANNER PREVERB + PATH PREVERB + VERB: Jaminjungan languages.

Germanic and Slavic are classified as satellite-framed languages (see, e.g., Slobin 2004: 25). Slobin states that The preferred means of expressing path is a nonverbal element associated with a verb. The typical construction type is MANNER VERB + PATH SATELLITE /.../ (Slobin 2004: 25). I argue that while colloquial English is saturated with path-expressions, Polish verbalises the original information with path, changes it, neutralises it, and also omits the original path or the motion event expressed in the English version. The following part focuses on strategies of expressing the path of motion lexicalised by the English version in translation into Polish.

\section{Rendering English utterances with Path into Polish}

The strategies that native speakers of Polish use when translating English path descriptions into Polish, which I observed in my earlier research (see Chłopek 2008a, b; 2010a, b), usually follow different lexicalisation patterns. Apart from the canonical representation of path by satellite-framed languages, through expressions with path satellites, there are also path constructions with different lexical categories in the Polish version, such as manner verbs and lexical adverbs. They evoke explicit paths in the Polish version. However, in the Polish version also occur utterances with nouns, adjectives, expressions that evoke usage-based knowledge. They make the original path ambiguous. The reading of the semantic component of path is subjective and vague on the basis of the Polish version with those categories. What is more, the translation version in Polish may not convey any path or may omit the whole motion event expressed by the English version. This part presents selected examples of those tendencies. First, within each sub-part, examples from the original, English, version are provided with numbers marked (a), corresponding to their Polish translation marked (b). The examples in the Polish version are translated into English, in brackets, by the author of this paper (Ch.). 
First, path satellites occur in both versions. Then, the Polish version has different lexical categories expressing ambiguous paths, open for subjective interpretations. Subsequently, the Polish version does not render the originally lexicalised path, and finally it does not evoke motion event, which is denoted by the English version.

\subsection{Path satellites in both versions}

In colloquial use, native speakers of English tend to communicate ideas by means of path, for example: Coming up (on a TV screen), Come over here, Take your hands off me. According to Talmy's typology, English conflates path to particles. Particles are adverbials accompanying root verbs, therefore Talmy calls them satellites. Polish also has satellites. They are verb prefixes. This section shows satellites in both versions.

\section{The English version}

The English examples from (1a) to (4a) denote the path with satellites and prepositions. Examples (1a) and (2a) have the satellite out conflating the path. The satellite out in (1a) means ${ }^{6}$ 'away from home or work'; the satellite out in (2a) means 'in a direction away from the inside or center'. In (3a) and (4a), the preposition into indicates 'entry, introduction, insertion, superposition, or inclusion'.

(1a) /.../, my parents will be out, said Gordon. (p. 17)

(2a) 'Breakfast,' she said as she pulled out her wand /.../. (p. 112)

(3a) He turned a corner into Magnolia Crescent /.../. (p. 13)

(4a) 'I'll take you to the door,' said Mrs Figg, as they turned into Privet Drive. (p. 27)

In the English version, the adverb out and the preposition into lexicalise specific paths. They also imply the configuration of the nominal referent completing the path. Nevertheless, the path particle or the preposition seem to take major stake in evoking the particular path.

${ }^{6}$ All definitions of English path satellites and prepositions used in this paper come from the Merriam-Webster dictionary at [URL:// http: merriamwebster.com]. 


\section{The Polish version}

The Polish version from (1b) to (4b) has constructions with satellites denoting the path. In (1b) and (2b), the verb prefix ${ }^{7} w y$ - is on two respective manner verbs - the present finite verb wybywaja and the present participle wyciagajac - with which it indicates 'movement from the inside to the outside, /.../' (Dubisz, T- $\dot{Z}$, 2006: 548). That path is equivalent to the path denoted by out in the English version in (1a) and (2a).

(1b) ‘.../ starzy wybywają - powiedział Gordon.' (p. 20) (/.../ my parents are going off - said Gordon.)

(2b) '- Śniadanie - powiedziała, wyciągając różdżkę /.../.' (p. 139) (- Breakfast - she said, pulling out her wand /.../.)

In (3b) and (4b), apart from the prefix $s$-, there are prepositional phrases $w$ + the nominal complement in the accusative case (acc.), which is a spatial case in Polish (see Krążyńska 2000: 41-42). It informs about "adlative" direction, which relates to motion towards the point of reference. What is more, Krążyńska emphasises that this meaning of the case exists only in spatial constructions (c.f. idem). The prefix $s$ - on the imperfective manner verb kręcic 'to turn', makes the verb perfective (see Dubisz, P-Ś, 2006: 1123). The prepositional phrase where the nominal complement is marked for the accusative case, naming the location, together with the preceding verb, evoke situations equivalent to those lexicalised by the expressions with into in the English version in (3a) and (4a).

(3b) 'Doszedł do rogu i skręcił w Magnolia Crescent.' (p. 15) (He reached the corner and turned into Magnolia Crescent.)

(4b) '- Odprowadzę cię do drzwi - powiedziała pani Figg, kiedy skręcili w Privet Drive -/...l' (p. 30) (I'll see you to the door - said Mrs Figg, as they turned into Privet Drive.)

Although Polish has satellites equivalent to those occurring in the English version, sometimes the constructions with satellites require more information to convey the specific path, like a prepositional phrase where a spatial complement is marked for a spatial case, such as the accusative case. Krążyńska explains that this fragmentary kind of relation of a preposition with a case that introduces the semantic component of "orientation" is described by the traditional perspective, represented, for example, by Klemensiewicz (1963: 20). According to that perspective, a preposition elaborates the meaning of the case (Krążyńska 2000: 42).

\subsection{Path constructions with different lexical categories in Polish}

The accurate path depicted by the English version is rendered into Polish by utterances with satellites and prepositional phrases or with other lexical cat-

\footnotetext{
${ }^{7}$ All definitions of Polish path satellites and prepositions in this article come from Uniwersalny stownik języka polskiego (2006, Warszawa, PWN).
} 
egories. In the latter case, the original exact path becomes ambiguous in the Polish version. This sub-part, after "the English version", illustrates near to the original paths, equivocal, or changed paths, which are expressed by sentences with: manner verbs, locative adverbs, a noun, an adjective, and a circumlocutory utterance that evokes usage-based knowledge.

\section{The English version}

The English version in (5a) - (11a) has satellites and prepositions. The satellite around denotes the path 'in a circle or in circumference' in (5a) and (6a). In (7a), the adverbial up and down evokes the path 'to and fro' or 'from one place to another'. In (8a), the satellite up evokes orientation 'in or into a higher position or level', the satprep down indicates the location 'toward or in a lower physical position'. In (9a), over lexicalises the path 'all through or throughout'. In (10a), the satellite $u p$ indicates an abstract path 'in or into a higher position or level'. That path is not real because it refers to a quality, not to a physical location; it is metaphorical. The orientational metaphors HIGH STATUS IS UP and GOOD IS UP, respectively (see Lakoff and Johnson 1980 [2003]: 16), license the usage of $u p$ in (10a). What is more, although up evokes a situation of static nature, Talmy's explanation justifies motion in that situation: The component of Motion (with capital $M$ ) refers to the presence per se of motion or locatedness in the event (Talmy: 2003 [2000]b: 25). In (11a), the satellite up, the converse of down, is used in the main sense: 'upward from the ground or surface'.

(5a) /.../; the eye whizzed around, staring at them all in turn. (p. 50)

(6a) These furious thoughts whirled around in Harry's head, /.... (p. 15)

(7a) Up and down he paced, consumed with anger and frustration, /.../. (p. 43)

(8a) /.../ and looked up at Fudge through the half-moon spectacles that rested halfway down his very crooked nose. (p. 127)

(9a) Most of the books he owned were strewn over the floor /.../. (p. 51)

(10a) 'Yeah,' Said Tonks, looking proud. 'Kingsley is as well, he's a bit higher up than me, though'. (p. 52)

(11a) He swung his right leg over his Firebolt, gripped its handle tightly and felt it vibrating very slightly, as though it was keen as he was to be up in the air one more. (pp. 54, 55)

The English version in (5a) - (11a) has satellites evoking the path, for example around in (5a) and (6a), up and down in (7a), up in (8a), in (10a), and in (11a), also satpreps, the satprep down in (8a) and over in (9a). The list of examples ranging from (5a) to (11a) with satellites or satpreps in the English version has different lexical means of expressing the original situations in the translation version from (5b) to (11b). Polish renders the original situations with different lexical categories, which do not encode the path by the standard of a satelliteframed language. 


\section{The Polish version}

The Polish version often makes use of other categories than prefixes on verbs in expressing the situations conveyed by the English version. The following examples (5b) - (11b) have manner verbs, locative adverbs, a noun, an adjective, and expressions that evoke usage-based knowledge. The semantic component of path is explicitly evoked by manner verbs and locative adverbs, respectively. Nevertheless, the noun nietad 'disarray, disorder', the comparative adjective lepszy 'better', and the expression that evokes usage-based knowledge wyrwac się do lotu, which could be explained into English as 'to break free/out flying', denote ambiguous paths. Those three circumlocutory expressions, however, may not trigger any spatial configuration. All of them trigger different areas of background knowledge. According to the four guiding principles that collectively characterise the collection of approaches falling within cognitive semantics, which were presented by Evans and Green: conceptual structure is embodied (principle 1), semantic structure is conceptual structure (principle 2), meaning representation is encyclopaedic (principle 3), and meaning-construction is conceptualisation (principle 4) (see 2006: 153-155), the reading of the Polish version of examples $(5 b)-(11 b)$ is open for subjective interpretations.

\section{- Manner verbs}

Examples (5b) and (6b) have manner verbs that have the reading equivalent to around in the English version. In (5b), the verb zawirować means 'to whirl'. In (6b), the reflexive verb kłębić się also means 'to whirl, to teem' in this context.

(5b) 'Oko zawirowało, łypiąc po kolei na każdego.' (p. 62) (The eye whirled, glowering at each of them in turn.)

(6b) Takie myśli kłębiły się w biednej głowie Harry’ego, /.../.' (p. 17) (Such thoughts whirled in Harry's poor head, /.../.)

\section{- Locative adverb and preposition}

In (7b), the adverbial expression tam i z powrotem has the sense 'there and back', equivalent to that expressed by up and down in the English version. In (8b), the preposition pośrodku (jego dtugiego haczykowatego nosa) 'in the middle of, in the centre (of his crooked nose)', may evoke the situation lexicalised by the English construction.

(7b) 'Krążył więc tam i z powrotem po sypialni, trawiony złością i bezsilną rozpaczą, /.../'. (p. 52) (So he circled there and back all over the bedroom, consumed with anger and helpless despair.)

(8b) \% .../ i spojrzał na Knota przez okulary - połówki, osadzone pośrodku jego długiego, haczykowatego nosa.' (p. 158) (/.../ and he looked at Fudge through the half-moon spectacles that rested in the middle of his long crooked nose.)

\section{- Noun}

In (9b), the prepositional phrase $w$ nieładzie evokes the path 'all through or throughout' with the nominal complement nietad 'disarray, disorder', which is 
expressed by the manner verb strewn and over in the English version. Nevertheless, that reading of $w$ nietadzie 'in disarray, disorder', is subjective as disarray or disorder mean different situations to different people. One may consider one book on the floor disarrayed, someone else will require two or more books on the floor to call the situation disarrayed.

(9b) 'Większość jego książek leżała w nieladzie na podłodze, /.../.' (p. 62) (Majority of his books lay on the floor in disarray.)

\section{- Adjective}

In (10b), the adjective lepszy 'better', triggers a conventionalised positioning 'in or into a higher position or level' (see merriamwebster.com) since the comparative degree of good - better - is metaphorically associated with the positive pole of the vertically oriented axis, in agreement with the orientational metaphors HIGH STATUS IS UP and GOOD IS UP (see Lakoff and Johnson 1980 [2003]: 16), mentioned earlier. This reading, however, based on concenceptual metaphors, is subjective. Therefore a conceptualiser may not perceive any orientation involving a path on the basis of the Polish version in (10b). The quality of being "better" will be triggered automatically without involving any visual background of a metaphorical path.

(10b) '- A tak - odrzekła z wyraźną dumą Tonks, - Kingsley też, ale on jest ode mnie trochę lepszy'. (p. 64) (- And yes - replied Tonks with clear pride, - Kingsley is as well, but he is a little better than me.)

\section{- Expression that evokes usage-based knowledge}

In (11b), a reader construes the direction 'upward from the ground or surface' on the basis of his or her usage based knowledge concerning the construction wyrwała sie do lotu 'broke free flying', which conveys the path through circumlocution. The post-prepositional noun phrase lotu 'flight', communicates the path 'upward from the ground or surface' through the readers' encyclopaedic knowledge about flights, airplanes, gravitation, etc. This knowledge triggers the upward direction of movement encoded in over in the English version.

(11b) 'Przerzucił prawą nogę przez Błyskawicę i uchwycił mocno jej rączkę, czując lekkie wibracje, jakby miotła wyrwała się do lotu z taką samą ochotą jak on'. (p. 67) (He swung his right leg over the Firebolt, and gripped its handle tightly, feeling slight vibrations, as though the broom broke free flying as willingly as him.)

While manner verbs and locative adverbs can convey overt paths, other lexical categories tend to be ambiguous as far as interpretations of spatial configurations are concerned, including the path of motion. Hence the Polish version has constructions with different lexical categories expressing the situations with path in the English version, it may be perceived as "reluctant" to codability of path. The English version has other constructions than those with satellites expressing the path, too, for example root verbs. Nevertheless, colloquial English is saturated with satellites evoking the semantic component of path. 


\subsection{Translation version in Polish with no explicit or ambiguous Path}

Although the Polish language can convey the path of motion encoded by English constructions with satellites, it either neutralises it or omits the path. While the English version in (12a) lexicalises a precise path, the Polish version (12b) does not specify that component of motion. In (12a), the satellite along /.../ entails moving or being parallel to something long such as a road, stream or fence (see Lindstromberg 1998: 83).

(12a) It was not easy to hold a Wand steady and haul Dudley along at the same time. (p. 25)

In the Polish version (12b), the manner verb ciagnać 'to drag, pull', does not denote a specific path of motion.

(12b) 'Nie było wcale łatwo panować nad różdżką i jednocześnie ciągnąć Dudleya.' (p.

30) (It was not easy to be in control of the wand and pull Dudley at the same time.)

The Polish manner verb ciagnać does not evoke movement taking place on something long, so the path 'along' is not unequivocally specified by that verb. The verb ciagnac has the reading 'pull with effort' (see Dubisz, A-J, 2006: 453), which is also attributed to the manner verb haul used in the English version. The current pattern includes a spatial scene lexicalised through the Polish version, however, that scene does not contain the semantic component of path.

\subsection{Translation version in Polish without Motion event}

The English examples (8a), (13a) and (14a) express complex paths. The Polish versions in (8b), (13b) and (14b) do not contain the whole spatial situations or they do not render certain fractions of the situations that include specific paths in the original sentences.

In (8b), the utterance $i$ spojrzat na Knota 'and he looked at Fudge', does not lexicalise the visual path of emanation 'in or into a higher position or level', expressed by the English version (8a) /.../ and looked up at Fudge. The path lexicalised by and looked up at Fudge in (8a) is a category of emanation paths well represented in language (Talmy 2003 [2000]a: 115). That is a category of sensory paths, including visual paths (idem).

In the English example (13a), the visual path of emanation is projected in the opposite direction to that in (8a). The complex path in (13a) is lexicalised by the satellites over and down and the satprep inside in looking inside or inside (the trunk). The complement the trunk is encoded implicitly; it is understood but not verbalised. The path denoted by looking down at the jumble in (13a) is a path of emanation, the motion is fictive (see idem, 103-105). In (13a), Tonks, the subject, projects her line of sight as a Probe along the path is specified by down and at relative to the reference object, which is lexicalised by the jumble inside. 
(13a) 'It's not very neat', Said Tonks, walking over to the trunk looking down at the jumble inside. (p. 52)

(13b) '- Za ładnie to nie wygląda - mruknęła Tonks, zaglądając do kufra.' (p. 64) (- It doesn't look good - muttered Tonks looking into the trunk.)

The Polish version in (13b) preserves the original information expressed by the fragment in italics: 'It's not very neat,' Said Tonks, looking into the trunk. It does not, however, verbalise the spatial scene evoking the particular paths of motion through the utterances with over and down, respectively. The path of motion to the other side, which is expressed by the satellite over in the English version in (13a), is omitted in the Polish translation. What is more, zagladajac do kufra 'looking into the trunk', does not denote the complete fictive emanated sensory path (see Talmy 2003 [2000]: 115) lexicalised by looking down at the jumble inside (the trunk). The Polish preposition do 'to', with the complement in the genitive case kufra 'trunk', evokes the destination of the path by the nominal complement. According to a dictionary definition explaining the situation, together with the noun that follows it, the preposition 'do' communicates the direction of movement, the destination of which is usually the interior of the object named by that noun (see Dubisz, A-J, 2006: 622). Therefore, since the noun kufer 'trunk', evokes the direction of movement, which is a threedimensional bounded object, a container, such path can be associated with expressions that evoke usage-based knowledge.

The path in the English example (14a) is real, the motion is factive (see Talmy 2003 [2000]a: 99-103). The first section of the path in (14a) is conflated to the satprep across, used in the meaning 'to or on the opposite side' of the kitchen. The second section of the path is evoked by the preposition into 'used as a function word to indicate entry, introduction, insertion, superposition, or inclusion'.

(14a) Where d'you think you're going?' yelled Uncle Vernon. When Harry didn't reply, he pounded across the kitchen to block the doorway into the hall. (p. 30)

The Polish version in (14b) does not verbalise the spatial scene with the path of motion that the English version evokes by the utterance he pounded across the kitchen.

(14b) '- A dokąd to się wybierasz? - ryknął wuj Vernon, a kiedy Harry nie odpowiedział, podbiegł do korytarza, by je zablokować swym ciałem.' (p. 36) (- And where are you going? - yelled uncle Vernon, and when Harry didn't reply, he ran up to the hall, in order to block the door with his body.)

What is more, the other section of the original path, conflated to into, is not expressed through podbiegt do korytarza 'he ran up to the hall', in the Polish version in (14b). The prefix pod-, paraphrasing Bojar (1979: 167), implies a very short distance between the objects after the former object has moved or has been transformed towards the latter one. Moreover, a verb of motion with the prefix pod-often occurs with the preposition $d o$ and the type of the caused action, i.e., manner of motion, is communicated by the verb stem (see Bojar, 
idem). The verb podbiegt has the prefix pod- and the stem biegt 'ran'. While the English version evokes two paths of motion through across the kitchen /.../ into the hall, the Polish version in (14b) omits the former spatial situation and alters or simplifies the latter one. A reader of the information conveyed by (14b) relies on his or her imagination and usage-based knowledge conceptualising the Polish version.

Nevertheless, usage-based knowledge is subjective, so is imagination, and creative thinking. What is not explicitly verbalised, may not be conceptualised.

\section{Conclusion}

The article pertains to Talmy's bi-categorial typology: satellite-framed languages and verb-framed languages in terms of conflating the semantic component of path, either to a satellite placed near a manner verb or to the verb root. English and Polish are both satellite-framed languages. Polish expresses the path with constructions with verb prefixes, which are bound satellites in Slavic, and with prepositions. However, in Polish, it is not a single preposition but the whole prepositional phrase that lexicalises the path since the nominal complements often precisely inform about that component of motion event. The nominal complements occurring within the list of examples in part two that are typically marked by case markers with spatial meaning are, for example Magnolia Crescent in the accusative case in skręcit $\boldsymbol{w}$ Magnolia Crescent in (3b) 'He turned into Magnolia Crescent' in (3a), swym ciatem in the dative case in by je zablokować swym ciatem in (13b) 'to block it with his body' in (13a), kufra in the genitive case in zagladajac do kufra in (14b) 'looking into the trunk' in (14a), and głowie Harry'ego in the locative case in $w$ glowie Harry'ego in (6b) 'in Harry's head' in (6a). The accusative case is a spatial case in Polish (see Krążyńska, op. cit.). It indicates directionality through the configuration implied by the referent lexicalised by a noun phrase with that marker. What is more, the information about the direction of movement of an object can also be conveyed by the genitive case, and by the dative case (see Dąbrowska 1997: 49). The locative case is specialised for conveying situations of being located in space in time (see Dubisz, K-Ó, 2006: 636).

The first part of the article attempts to present certain basic assumptions of Talmy's bi-categorial typology focusing on the path. It emphasises the fact that English and Polish are both satellite-framed languages and despite this classification the two languages differ in respect to expressing similar ideas. While English makes use of the semantic component of path, Polish reduces that element of spatial situations in translation versions. The first part also mentions other articles, concerned with cognitive analyses of prepositions in the Polish language and with prepositions in Slavic. A series of articles, compiled in a single volume (Hasko and Perelmutter 2010), relates to Talmy's typology. The analyses mostly focus on the manner of motion, although there are also references to path. This paper focuses on path. 
The second part is the main body of this article. It introduces four patterns that may be observed following translations of colloquial English into Polish. Apart from the pattern that is equivalent to expressing the path of motion in the English language, there are patterns of lexicalisation not making use of satellites in Polish. The objective of the second part is to illustrate the lexicalisation patterns of rendering path descriptions in Polish translation from English.

One may observe typological similarities and differences between English and Polish. They occur at the constructional and discourse level. The differences result from convention based on the fact that Polish is a highly inflectional language, which gives it more freedom in the order of arranging the components in the linear structure of a sentence. It has impact on discourse. Examples like Coming up (on a TV screen) (Pol. Za chwile (Eng. In a moment)), Come over here (Pol. Chodź tutaj [Eng. Come here]), It is over there (Pol. To jest tam [Eng. It is there]), This is what you said back in $1997^{8}$ (Pol. To powiedziates' w 1997 [Eng. This is what you said in 1997]), Take your hands off me (Pol. Zostaw mnie [Eng. Leave me]), etc., show that certain basic ideas that have path in English verbal communication, are expressed without path in Polish, which is the matter of convention. Convention also determines saying, for example, zagladajac do 'looking into', which has 37 results in the PWN Corpus (op. cit), instead of zagladajac $w$ dót do 'looking down into', which has no results in the PWN Corpus (idem). The Polish version with $w$ dót is not statistically equivalent in Polish communication to the English version with down. What is more, a native speaker of Polish will not say, for example, spoglądając w górę na księżyc 'looking up at the moon', he or she will rather say spogladajac na księżyc 'looking at the moon', basing the expression on usage-based knowledge that the moon is up. While the utterance spogladajac na 'looking at', has 45 results in the PWN Corpus (idem), the utterance spogladajac $w$ góre na 'looking up at', has no results in that corpus. What is more, while English has a number of verbs that genuinely incorporate path (1985 [2007]: 92), such as: enter, exit, descend, etc., together with colloquial verbs with satellites, such as come in, go out, go down, etc., Polish has verbs with prefixes that are translation equivalents of the former and the latter verbs, for example wejść, wyjść, zejść, etc. English has satellites in colloquial speech and verb roots that genuinely incorporate path in formal usage. Polish, however, has satellites, verb prefixes, in both: colloquial and formal usage. This also influences the lexicalisation patterns in Polish.

It is interesting what results may come out of a close research into verbal communication recorded in the form of the language corpus on the Internet. It may be hard, however, to match translation versions of language corpora in English and in Polish or other Slavic languages because the corpora have different data. What is more, the internet corpora do not contain all expressions present in verbal communication. For example, the rude utterance Zabierz ode mnie swoje łapy 'Take your grabbers off me', has no results in the PWN Corpus

\footnotetext{
${ }^{8}$ The source of this example: BBC World television channel, programme "Hard Talk" on the $14^{\text {th }}$ July, 2011.
} 
and in the PAN Corpus, respectively. Nonetheless, Polish people use it, which can be observed "in the world around us", known intuitively or through the Google search box.

\section{REFERENCES}

Bożenna BOJAR, 1979: Opis semantyczny czasowników ruchu oraz pojęć związanych z ruchem. Warszawa: Wydawnictwa Uniwersytetu Warszawskiego.

Dwight BOLINGER, 1971: The Phrasal Verb in English. Cambridge: Harvard University Press.

Dorota CHŁOPEK, 2010a: English constructions with directional particles and prepositions - patterns of Polish translation. Ed. Mario Brdar. Osijek. (Jezikoslovlje 11.2). $155-195$.

- -, 2010b: "Landscape" verbalised through English in translation into Polish: Similarities and differences. Ed. Richard Repka. Sládkovičovo: Vysoká Škola Visegrádu v Sládkovicove. (Fórum cudzích jazykov 2). 25-38.

- -, 2008a: Scenes Constructed by English Spatial Particles Expressed in Polish. Bielsko-Biała: Wydawnictwo ATH.

- -, 2008b: Angielskie partykuly przestrzenne w tlumaczeniu na język polski: aspekty semantyczne i pragmatyczno-pojęciowe. Bielsko-Biała: Wydawnictwo ATH.

Ewa DĄBROWSKA, 1997: Cognitive Semantics and the Polish Dative. Berlin: Mouton de Gruyter.

Stanisław DUBISZ (ed.), 2006: Uniwersalny słownik języka polskiego, A-J, K-Ó, P-Ś, $T$-Ż. Warszawa: Wydawnictwo Naukowe PWN.

Vyvyan EVANS, Melanie GREEN, 2006: Cognitive Linguistics: An Introduction. Edinburgh: Edinburgh University Press.

Luna FILIPOVIĆ, 2010: The importance of being a prefix: Prefixal morphology and the lexicalization of motion events in Serbo-Croatian. Eds. Victoria Hasko, Renee Perelmutter. Amsterdam and Philadelphia: John Benjamins. (New Approaches to Slavic Verbs of Motion). 247-266.

Kira GOR, Svetlana COOK, Vera MALYUSHENKOVA, Tatyana VDOVINA, 2010: Russian verbs of motion: Second language acquisition and cognitive linguistics perspectives. Eds. Victoria Hasko, Renee Perelmutter. Amsterdam and Philadelphia: John Benjamins. (New Approaches to Slavic Verbs of Motion). 361-381.

Rodney D. HUDDLESTON, Geoffrey K. PULLUM, 2002: The Cambridge Grammar of the English Language. Cambridge: Cambridge University Press.

Zenon KLEMENSIEWICZ, 1963: Zarys składni polskiej. Warszawa: Wydawnictwo Naukowe PWN. 
Anetta KOPECKA, 2010: Motion events in Polish: Lexicalization patterns and the description of Manner. Eds. Victoria Hasko, Renee Perelmutter. Amsterdam and Philadelphia: John Benjamins. (New Approaches to Slavic Verbs of Motion). 225-246.

Zdzisława KRĄŻYŃSKA, 2000: Staropolskie konstrukcje z przyimkami. Vol. I. Poznań: Wydawnictwo WiS.

George LAKOFF, Mark JOHNSON, 2003 [1980]: Metaphors We Live By. Chicago and London: The University of Chicago Press.

Seth LINDSTROMBERG, 1998: English Prepositions Explained. Amsterdam and Philadelphia: John Benjamins Publishing Company.

Tatiana NIKITINA, 2010: Variation in the encoding of endpoints of motion in Russian. Eds. Victoria Hasko, Renee Perelmutter. Amsterdam and Philadelphia: John Benjamins. (New Approaches to Slavic Verbs of Motion). 267-290.

Ekaterina V. RAKHILINA, 2010: Verbs of rotation in Russian and Polish. Eds. Victoria Hasko, Renee Perelmutter. Amsterdam and Philadelphia: John Benjamins. (New Approaches to Slavic Verbs of Motion). 291-316.

Zygmunt SALONI, Marek ŚWIDZIŃSKI, 2007: Składnia współczesnego języka polskiego. Warszawa: Wydawnictwo Naukowe PWN.

Dan I. SLOBIN, 2004: The Many Ways to Search for a Frog: Linguistic typology and the expression of motion events. Eds. Sven Strömqvist, Ludo Verhoeven. Mahwah, NJ: Lawrence Erlbaum Associates. (Relating events in narrative: Vol. 2. Typological and contextual perspectives). 219-257.

--, 2003: Language and Thought Online: Cognitive Consequences of Linguistic Relativity. Eds. Dedre Gentner, Susan Goldin-Meadow. Massachusetts Institute of Technology. (Language mind: advances in the study of language and thought). 157-190.

Leonard TALMY, 2003 [2000]b: Toward a Cognitive Semantics. Vol. I: Concept Structuring Systems. Cambridge, Massachusetts/London, England: The MIT Press.

- -, 2003 [2000]b: Toward a Cognitive Semantics. Vol. II: Typology and Process in Concept Structuring. Cambridge, Massachusetts/London, England: The MIT Press.

- -, 2007 [1985]: Lexical Typologies. Ed. Timothy Shopen. Cambridge: Cambridge University Press. (Language Typology and Syntactic Description. Vol. III: Grammatical Categories and the Lexicon). 66-168.

Zofia ZARON, 2005: Wyktadnikami lokalizacji-konstrukcje przystówkowe czy przyimkowe? Ed. Maciej Grochowski. Toruń: Wydawnictwo Uniwersytetu Mikołaja Kopernika. (Przysłówki i przyimki. Studia ze składni i semantyki języka polskiego). 45-55.

THE SOURCES OF THE EXAMPLES FROM (1) TO (15)

Joanne K. ROWLING, 2003: Harry Potter and the Order of Phoenix. London: Bloomsbury Publishing. 7-80.

Joanne K. ROWLING, 2004: Harry Potter i Zakon Feniksa. Translated by Andrzej Polkowski. Poznań: Harbor Point Sp. z o.o. Media Rodzina. 


\section{VZORCI LEKSIKALIZACIJE OPISA POTI V POLJSKIH PREVODIH IZ ANGLEŠČINE}

Prispevek se nanaša na Talmyjevo izrazito dvokategorijalno tipologijo jezikov, $\mathrm{v}$ kateri so izpostavljeni jeziki, ki pot ali cilj označijo zunaj glagolskega okvira (»satelitsko uokvirjeni jeziki«), ter jeziki, ki pot ali cilj označijo znotraj glagola (»glagolsko uokvirjeni jeziki«), in sicer v smislu združevanja semantične komponente poti - bodisi kot »satelitsko« umeščene ob načinovni glagol ali ob glagolski koren. Ta tipologija je po Slobinu razširjena z uvedbo razreda ekvivalentno uokvirjenih jezikov. Angleščina in poljščina sta satelitsko uokvirjena jezika, pri čemer angleščina pogovorno izraža ideje s strukturami, ki leksikalizirajo natančno pot skozi satelite, poljski prevod pa to pot nevtralizira, spreminja ali opušča pot, izraženo v originalu.

V prvem delu prispevka so ob osredinjenju na semantično komponento poti nakazane določene temeljne predpostavke Talmyjeve dvokategorijalne tipologije. V jedrnem delu so predstavljeni vzorci leksikalizacije opisa poti v poljščini, opaženi pri spremljanju prevodov pogovorne angleščine $\mathrm{v}$ poljščino. Poljščina kot satelitsko uokvirjeni jezik leksikalizira semantično komponento poti s sateliti - struktura z glagolskimi predponami - in tudi s predložnimi zvezami. Za razliko od vzorca, ki je ekvivalenten izražanju poti gibanja $\mathrm{v}$ angleškem jeziku, poljski prevod vsebuje drugačna (na rabi temelječa) leksikalna sredstva, ki nakazujejo pot, npr. načinovni glagoli, krajevni prislovi, samostalniki, pridevniki in opisovanje okoliščin. Vendar ta leksikalna sredstva kažejo dvoumne poti, odprte za subjektivno interpretacijo. Zaključek ponuja možne vzroke za vzorce leksikalizacije v poljščini. 